\title{
KEHANDALAN ALKITAB MENJADI FONDASI BAGI PENGAJARAN TENTANG YESUS KRISTUS
}

\author{
Aprianus Ledrik Moimau \\ Sekolah Tinggi Teologi Injili Arastamar (SETIA) Jakarta \\ aprianus@sttsetia.ac.id
}

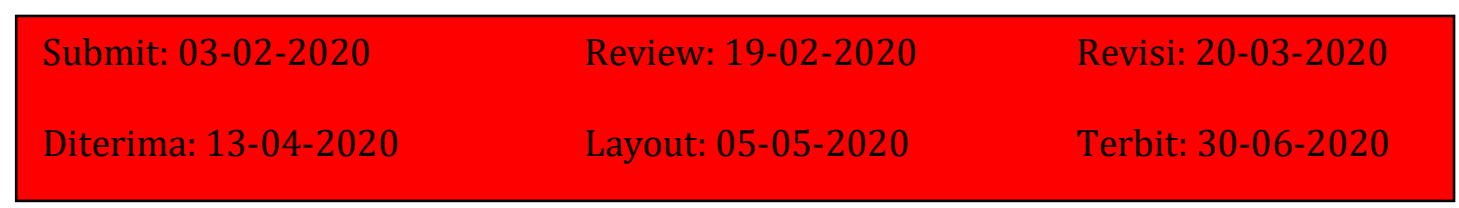

\begin{abstract}
The Bible which is the source of Christian teaching has been doubted by saying that the Bible has been falsified and cannot be used as a basis in building Christian teachings, especially regarding the person of Jesus Christ. The gospels which are the primary source of Jesus Christ have been falsified and as such cannot be the basis for finding the real Jesus. Bible truth and reliability, especially the Gospels are questioned. If the Bible is relied upon in building knowledge and faith in Jesus Christ, what are the criteria in determining the reliability of the Bible? The purpose of this study is to find out whether the Bible has reliability that can be used as a standard in building Christian doctrines, especially regarding the person of Jesus Christ. In this study, a study was conducted on aspects of biblical bibliography, internal evidence tests and tests. external. Based on research conducted on the Bible, historical search, Bible data and from external evidence carried out by taking a test of historical truth, the Bible has a deepness in building Christian doctrines, specifically the Gospels have a depth in finding and believing in Jesus Christ stated in the Bible. The reliability of the Bible is proven and thus the person of Jesus Christ exposed by the Bible is true.
\end{abstract}

Keywords: Reliability, Bible, Jesus Christ

\begin{abstract}
Abstrak
Alkitab yang merupakan sumber ajaran Kristen telah diragukan dengan mengatakan bahwa Alkitab telah dipalsukan dan tidak dapat jadikan sebagai dasar dalam membangun ajaran-ajaran Kristen, khususnya mengenai pribadi Yesus Kristus. Injil-Injil yang merupakan sumber primer tentang Yesus Kristus telah dipalsukan dan dengan demikian tidak dapat menjadi dasar dalam mencari Yesus yang sesungguhnya. Kebenaran dan kehandalan Alkitab, khususnya Injil-Injil dipertanyakan. Jika Alkitab diandalkan dalam membangun pengetahuan dan iman kepada Yesus Kristus, apa yang menjadi kriteria dalam menentukan kehandalan Alkitab? Tujuan penelitian ini adalah untuk mengetahui apakah Alkitab memiliki kehandalan yang dapat dijadikan sebagai standar dalam membangun doktrin-doktrin Kristen, khususnya mengenai pribadi Yesus Kristus. Dalam penelitian ini, dilakukan kajian terhadap aspek bibliografi Alkitab, tes bukti internal dan tes . eksternal. Berdasarkan penelitian yang dilakukan terhadap Alkitab, penelusuran historis, data-data Alkitab dan dari bukti eksternal yang dilakukan dengan mengikuti tes kebenaran historis maka Alkitab memiliki kehandalam dalam membangun doktrin-doktrin Kristen, secara khusus Injil-Injil memiliki kehandalam dalam menemukan dan percaya kepada Yesus Kristus yang dinyatakan dalam Alkitab. Kehandalan Alkitab terbukti dan dengan demikian pribadi Yesus Kristus yang dipaparkan Alkitab adalah benar.
\end{abstract}

Kata Kunci: Kehandalan, Alkitab, Yesus Kristus 


\section{Pendahuluan}

Sistem nilai yang membentuk kepecayaan suatu golongan atau agama tertentu dibangun di atas dokrin-doktrin atau ajaran-ajaran kelompok atau agama tersebut. Demikian pula sistem nilai atau kepercayaan dalam kekristenan, dibangun diatas teksteks Alkitab. Pembuktian bahwa ajaran Kristen yang dibangun valid, harus bermula dalam Alkitab. Kevalitan ajaran-ajaran dalam kekristenan haruslah bermula pada kebenaran atau kehandalan Alkitab. Jika Alkitab diyakini kehnadalannya, maka doktrindoktrin atau ajaran-ajaran yang dibangun di atas dasar Alkitab dapat pula diyakini kebenarannya. Kebenaran doktrin-doktrin atau ajaran-ajaran Kristen seperti ajaran tentang Allah yang transenden dan imanen, manusia yang adalah gambar dan rupa Allah tetapi akhirnya menjadi hamba dosa, ajaran tentang Yesus Kristus yang memiliki dua natur yakni natur Allah dan manusia, ajaran tentang kesalamatan hanya dalam Yesus, ajaran tentang akhir zaman, semuanya bergantung pada kebenaran atau kehandalan Alkitab. Maka dalam artikel ini akan dibahas apakah Alkitan dapat diandalkan dalam membangun doktri-doktrin Kristen secara khusus kebenaran ajaran tentang Yesus Kristus.

\section{Metodetodologi}

Dengan berbagai pandangan yang muncul terhadap Alkitab, maka penelitian ini difokuskan pada pengamatan terhadap kebenaran dan kehandalan Alkitab dalam membangun doktrin-doktrin Kristen. Dalam meneliti kebenaran dan kehandalan Alkitab, penelitian ini mengacuh pada criteria kebenaran dan kehandalan dengan menggunakan criteria yang netral.

\section{Pembahasan}

Dalam pembuktian kebenaran teks-teks Alkitab (Perjanjian Baru) sebagai landasan atau dasar pembuktian superioritas Yesus, penulis mengacuh pada kriteria yang dibuat oleh C. Sanders. Menurut Sanders, ada tiga prinsip dasar pengujian terhadap kebenaran sejarah yakni: Tes Bibliografi atau kepustakaan, tes bukti internal dan tes bukti eksterna. ${ }^{1}$ Berdasarkan tiga prinsip yang diajukan oleh Sander, penulis akan melihata Kredibilitas atau kehandalan teks-teks Alkitab, secara khusus Perjanjian Baru (InjilInjil).

\section{Tes Bibliografi atau Kepustakaan².}

Bagaimana proses naskah-naskah Perjanjian Baru (Injil-Injil) dari yang asli (autograf) sampai yang ada di tangan kita sekarang? Mengingat naskah asli dari teksteks Perjanjian Baru tidak ada lagi, maka bagaimana kita dapat yakin bahwa naskah

${ }^{1}$ C. Sanders, Introduction in Research in English Literary History (New York: Macmillan Co, 1952), 143.

${ }^{2}$ Tes Bibliografi atau Kepustakaan adalah penelitian terhadap proses perjalanan naskah dari yang asli sampai kepada bentuknya yang sekarang ada di tangan kita. 
salinan yang ada sekarang (baik yang tersimpaan di perpustakaan-perpustakaan maupun yang kita miliki dalam bentuk Alkitab) sesuai dengan aslinya? Hal ini membawa kita untuk mempertimbangkan jauh ke belakang: mengapa infomasi tentang Yesus dari saksi mata yaitu murid-murid Yesus atau orang yang dekat dengan murid-murid Yesus baru ditulis puluhan tahun setelah Yesus terangkat ke surga? Teori penulisan KitabKitab Injil ${ }^{3}$ mana pun yang dianut seseorang atau suatu kelompok jelas bahwa Injil-Injil mengenai Yesus ditulis puluhan tahun setelah Yesus terangkat ke Surga.

Mengapa kisah-kisah tentang Yesus baru ditulis setelah interval waktu yang cukup Lama? Sekiranya Injil-Injil langsung ditulis oleh mereka yang adalah saksi mata dari kehidupan dan pelayanan Yesus segera setelah Yesus tengkat ke surga, maka kebenaran kisah Yesus tidak perlu diragukan. Dalam menjawab persoalan ini, Komoszewski dkk menyatakan bahwa pertanyaan tentang mengapa ada penundaan penulisan kisah Yesus salah perspektif, pertanyaan yang seharusnya ditanyakan adalah: mengapa kisahkisah tentang Yesus akhirnya ditulis? ${ }^{4}$ Jika jawaban diacuh dari pertanyaan pertama maka kita dapat berasumsi bahwa sudah ada rencana untuk menulis kisah-kisah tersebut.

Komoszewski dkk menyatakan bahwa perintah Yesus kepada para rasul adalah untuk memberitakan Injil, sehingga motivasi yang ada dalam pikiran para rasul adalah pewartaan kabar baik, bukan motivasi untuk membukukan kisah-kisah Yesus dari Nazareth. ${ }^{5}$ Para rasul mendapat tugas dari Yesus untuk memberitakan kabar baik yang menyelamatkan tidak hanya di Yerusalem, melainkan sampai ujung bumi. Setelah para rasul menerima Roh Kudus pada hari Pentakosta, mereka memberitakan Injil mulai dari Yerusalem sesuai dengan perintah Yesus.

\footnotetext{
${ }^{3}$ Beberapa teori pembentukan Kitab-kitab Injil dapat dipaparkan di sini: 1. Para penulis injil bergantung pada satu Injil yang asli. Bahwa para penulis Injil menggunakan secara terpisah sebuah Injil yang sama yang tertulis dalam bahasa Ibrani atau Aram. Ini merupakan teori dari seorang sarjana Jerman, G.E. Lessing (1771). Injil ini disebut dengan Injil-Asli. 2. Para penulis injil bergantung pada sebuah tradisi lisan. Tradisi lisan ini telah fixed dan oleh karena itu ada kesamaan yang sangat tinggi persentasinya. 3. Para penulis injil bergantung pada fragmen-fragmen tertulis yang berkembang secara bertahap. 4. Para penulis injil saling bergantung satu dengan yang lain ketika menulis injil-injil mereka. Ini adalah teori terakhir dan paling banyak diterima sekarang dengan variasi yang berbeda-beda. Ada banyak variasi mengenai teori saling bergantung ini: a. Proposal dari Agustinus. Menurut Agustinus, Matius ditulis lebih dahulu, kemudian Markus memakai Matius, dan Lukas paling terakhir memakai Matius dan Markus. b. Hipotesis Dua Injil. Matius ditulis terlebih dahulu, kemudian Lukas dan terakhir Markus, meringkaskan Matius dan Lukas. Ini hipotesis dari J.J. Griesbach [1789]. Hipotesis ini mulai populer lagi pada tiga puluht tahun terakhir ini. C. Hipotesis Dwi Sumber. Kitab Markus dan Q (= Quelle (bah. Jerman), yaitu sumber), perkataan-perkataan Yesus yang hilang adalah sumber dari penulisan dua Injil sinoptik lain. Pertama kali dimunculkan oleh Karl Lachmaan dan C.G. Wilke, tetapi kemudian dikembangkan oleh C.H. Weisse (18011866) kemudian didukung oleh H.J. Holtzmann (1832-1910). Holtzmann kemudian merekonstruksi kehidupan Yesus yang historis atas dasar Injil Markus. Weisse mengusulkan teori dwisumber untuk InjilInjil sinoptis, yaitu Markus dan Q. d. Empat sumber : Markus, Q, L, dan M. Markus, Q, L [bahan yang hanya ada di Lukas] dan M [bahan yang hanya ada di Matius (Lihat Paul Paul J. Achtemeier, Joel B. Green, and Marianne Meye Thompson, Introduction The New Testament. Its Literature Theology (Grand Rapids: Eerdmans, 2001), 65-75; B. E. Drewes, Satu Injil Tiga Pekabar (Jakarta: BPK Gunung Mulia, 2006).

${ }^{4}$ J. ED. Komoszewski, M. James Sawyer, and Daniel B. Wallace, Reinventing Jesus. Bagaimana Para Pemikir Skeptis Keliru Memahami Yesus Dan Menyesatkan Budaya Populer (Jakarta: Literatur Perkantas, 2011), 23.
}

${ }^{5}$ Ibid., 30-31. 
Dalam Kisah para rasul kita melihat bagaimana jumlah mereka yang percaya terus bertambah, oleh karena para rasul memberi perhatian yang penuh terhadap pewartaan kabar baik. Para saksi mata masih hidup dan giat dalam pelayanan misi, maka jelas bahwa pedoman tertulis tentang Yesus belum diperlukan. Pertanyaan selanjutnya adalah: mengapa akhirnya kisah-kisah tentang Yesus harus ditulis? Komoszewski dkk berpendapat bahwa umumnya para ahli memberikan dua/tiga alasan mengapa kisah tentang Yesus dibukukan, yakni: pertama, para rasul yang adalah saksi mata dari pribadi dan pelayanan Yesus mulai meninggal. Jika mereka yang adalah saksi mata meninggal tanpa adanya sumber yang diacuh oleh Gereja mula-mula dalam pewartaan kabar baik maka dapat dibayangkan bahwa kisah-kisah tersebut dapat ditambahkan atau dikurangi. ${ }^{6}$ Kedua, kedatangan Tuhan kembali, tidak terjadi dalam waktu dekat. Gereja terus bertumbuh dan tersebar luas (Kis. 2:47; 6:7; 9:31; 12:24; 13:49; 16:5; 19:20; 28:31) sehingga diperlukan kisah yang tertulis. ${ }^{7} \quad$ Ketiga, Pewartaan kabar baik mulai tersebar luar dan gerakan gerakan itu sangat cepat, maka diperlukan pedoman dalam pewartaan dan kehidupan mereka yang percaya.

Dengan demikian jelaslah bahwa pembukuan cerita tentang Yesus tidak direncanakan sebelumnya oleh mereka yang adalah saksi mata, melainkan karena kebutuhan dan kondisi yang terjadi dalam pemberitaan kabar baik. Di sisi yang lain, para penulis juga mempunyai alasan-alasan dan tujuan tertentu dalam penulisan untuk para pendengar, sehingga alasan penulisan tidak seperti yang disampaikan para ahli. Yang penting ialah bahwa para rasul berfokus pada pemberitaan Injil secara lisan sehingga kisah-kisah dibukukan puluhan tahun kemudian.

Meskipun demikian, pertanyaannya belum terjawab: bagaimana mungkin dalam rentang waktu yang puluhan tahun tersebut tidak ada penambahan atau pengurangan cerita tentang Yesus? Funk dan Kelompok Yesus seminar menyatakan bahwa banyak cerita yang tercatat dalam kitab-kitab Injil merupakan cerita rakyat, artinya cerita itu telah disunting, dihapus, ditambah dan berbaur berulang kali selama bertahun-tahun. ${ }^{8}$ Terhadap masalah ini, Komoszewski dkk memberi beberapa catatan yang meyakinkan bahwa kisah tentang Yesus yang tulis sama dengan kisah yang beredar secara lisan sebagai kabar baik. Pertama, Kisah-kisah tentang Yesus dan ucapan-ucapan-Nya diulang ratusan bahkan ribuan kali oleh lusinan saksi mata. ${ }^{9}$ Kedua, kurun waktu pewartaan lisan memiliki beberapa implikasi bagi ketepatan Injil-injil tertulis. Setelah hari Pentakosta, maka kisah-kisan tentang Yesus tersebar dengan cepat dan luas kepada khalayak ramai (bahkan sebelum hari Pentakosta banyak orang yang mengetahui kegiatan-kegiatan Yesus karena banyak orang berbondong-bondong mengikuti Yesus) sampai kisah-kisah tersebut ditulis. Oleh karena kisah-kisah tentang Yesus telah tersebar dengan cepat dan luas maka jika kisah-kisah yang ditulis antara 30 tahun setelah Yesus terangkat ke surga tersebut berbeda dengan kisah-kisah lisan yang telah

\footnotetext{
${ }^{6}$ Ibid.

${ }^{7}$ Ibid.

${ }^{8}$ Robert W. Funk and Jesus Seminar, The Acts of Jesus: The Search of the Authentic Deeds of Jesus (San Fransisco: HarperSanFransisco, 1988), 6.

9 Para saksi mata menghidupi kisah-kisah tentang Yesus, dan kisah-kisah itu terus diwartakan kepada orang lain, sehingga kita dapat membayangkan bahwa para saksi mata tersebut mengingat semua peristiwa berhubung dengan Yesus Kristus. (Lihat Komoszewski, Sawyer, and Wallace, Reinventing Jesus. Bagaimana Para Pemikir Skeptis Keliru Memahami Yesus Dan Menyesatkan Budaya Populer, 34.
} 
beredar dengan luas setidak-tidaknya ada protes atau keberatan sehubungan dengan perbudaan kisah yang tertulis dan yang telah beredar secara lisan. ${ }^{10}$ Ketiga, Pewartaan yang dilakukan pada hari Pentakosta dan seterusnya tidak dapat lagi dikendalikan isinya. Setelah Injil tersebar, para rasul tidak dapat mengubahnya lagi. ${ }^{11}$

Dengan demikian, maka jika ada konspirasi untuk pemutabalikan kisah-kisah tentang Yesus, sudah dilakukan sebelum hari pentakosta, sesuatu hal yang tidak mungkin karena situasi ketakutan yang dialami oleh murid-murid Yesus seperti yang dinyatakan dalam Alkitab (Yoh. 20:19) dan waktunya yang relatif singkat untuk membuat konspirasi. Akan tetapi ini pun agaknya tidak mungkin karena kisah-kisah tersebut diketahui juga oleh orang banyak, sehingga konspirasi dan pemutarbalikan terhadap kisah-kisah Yesus akan terlihat dengan jelas dan mendapat protes dari para pendengar Yesus yang sangat banyak tersebut.

Teori konspirasi pemutabalikan kisah-kisah Yesus mengandung begitu banyak kelemahan dan harus ditolak. Vincent Tylor menyatakan bahwa karena banyaknya saksi mata dan pengikut Yesus yang tersebar setelah pentakosta untuk menceritakan apa yang terjadi sehubungan dengan Yesus, maka teori konspirasi menampilkan lini depan yang sangat lemah. ${ }^{12}$ Para kritikus juga membuat kriteria untuk menentukan perkataan dan tindakan mana saja yang benar berasal dari Yesus dan mana yang tidak berasal dari Yesus, berasal dari Yudaisme atau dari kekristenan. Kriteria ini disebut kriteria autentisitas atau kriteria keautentikan. ${ }^{13}$ Pertama, Kriteria Ketidakmiripan atau Perbedaan. Para kritikus menyatakan bahwa jika suatu ucapan atau tindakan Yesus berbeda dengan tradisi Yudaisme dan kekristenan maka tindakan atau ucapan Yesus itu dianggap otentik (asli) berasal dari Yesus. Jika perkataan atau ucapan Yesus memiliki kesamaan dengan Yudaisme atau kekristenan maka dianggap bukan berasal dari Yesus, perkataan itu ditaruh di mulut Yesus oleh kelompok Yudaisme atau oleh orang Kristen. ${ }^{14}$

Terhadap kriteria ketidakmiripan atau perbedaan ini, Evans menyatakan bahwa kita tidak dapat menghapus atau memisahkan Yesus dari Yudaisme karena Yesus adalah orang Yahudi dan sebagian besar hal yang diajarkan adalah tema dan konsep yang populer di antara para pemimpin agama Yahudi di zaman-Nya, dan juga Yesus tidak dapat dipisahkan dari kekristenan karena kekristenan bersumber dari Yesus. ${ }^{15}$ Jika kita memisahkan Yesus dari Yudaisme dan dari kekristenan maka yang tinggal hanya Yesus yang eksentrik. ${ }^{16}$ Jika kedua sisi yakni Yudaisme dan kekristenan harus dipisahkan dari Yesus maka, Yesus sebagai sosok yang ganjil yang terpisah dari warisan budaya dan secara ideologis terasing dari gerakan yang dipelopori-Nya. ${ }^{17}$

10 Ibid., 34-35.

11 Ibid., 35.

12 Vincent Tylor, The Formation of the Gospel Tradition (London: Macmillan, 1933), 42.

13 Craig Evans, Merekayasa Yesus. Membongkar Pemutarbalikan Injil Oleh Ilmuwan Modern (Yogyakarta: ANDI Offset, 2005), 39.

14 Ibid., 43-44.

15 Ibid.

16 Komoszewski, Sawyer, and Wallace, Reinventing Jesus. Bagaimana Para Pemikir Skeptis Keliru Memahami Yesus Dan Menyesatkan Budaya Populer, 46.

${ }^{17}$ Darrell L. Bock, "The Words of Jesus in the Gospels: Live, Jive, or Memorex?," in Jesus Under Fire: Modern Scholarship Reinvents the Historical Yesus, ed. Michael J. Winkins and J. P Moreland (Grand Rapids: Zondervan, 1995), 91. 
Kriteria ketidakmiripan atau perbedaan ini dipakai dengan tendesi negatif oleh para ahli, tetapi seharusnya dipakai dengan tendensi positif: jika perkataan dan perbuatan Yesus memiliki persamaan dengan Yudaisme dan kekristenan maka pasti berasal dari Yesus, karena benar bahwa Yesus tidak dapat dipisahkan dari Yudaisme karena Yesus seorang Yahudi dan dari kekristenan karena kekristenan berasal dari Yesus Kristus. Kedua, kriteria Kesaksian Ganda/Kolektif. Jika perkataan Yesus terdapat atau tercatat dalam dua atau lebih sumber independen, maka perkataan itu benar berasal dari Yesus, sebaliknya jika perkataan tersebut hanya terdapat dalam satu sumber maka kesaksian itu tidak berasal dari Yesus. ${ }^{18}$ Terhadap kriteria ini, Evans memberi sanggahan dengan menyatakan: "fakta bahwa ada banyak bahan yang mendapatkan pembuktian kolektif itu sendiri merupakan saksi kekunoan dan kekayaan sumber kita."19

Komoszewski dkk megatakan bahwa jika kriteria ini diterapkan secara ketat maka Yesus mengalami pengurangan dan juga menjadi Yesus yang ganjil. Jika Kriteria ini diterapkan terhadap seorang tokoh sejarah maka dapat dibayangkan betapa banyaknya ucapan mereka yang harus kita buang dan dengan demikian mereka tidak lagi menjadi tokoh sejarah yang dimaksud. ${ }^{20}$ Jika kriteria ini diterapkan pada tokoh sejarah yang lain, maka banyak perkataan mereka yang harus dibuang karena tidak terdapat dalam dua atau lebih sumber. Ketiga, Kriteria Koherensi. Menurut kriteria ini, apapun juga yang ditemukan para ahli dalam kitab-kitab Injil tentang Yesus, penemuan itu harus sesuai atau koheren dengan gambar lainnya yang telah dilukiskan oleh para ahli tentang Yesus yang sejati atau Yesus yang historis. ${ }^{21}$ Kriteria ini tidak dapat dipakai karena pada kriteria ketidakmiripan dan kriteria kesaksian ganda, para ahli kritik tidak konsisten. ${ }^{22}$

Jika para ahli telah menemukan Yesus dalam kitab-kitab Injil, maka seharusnya juga Yesus yang dilukiskan para ahli harus sesuai atau koheren dengan gambar Yesus dalam kitab-kitab Injil. Gambar Yesus versi para ahli berbeda dengan gambar Yesus versi Alkitab karena para ahli tidak mamakai Alkitab sebagai sumber sebaliknya mereka memilih untuk menjauhi Alkitab dalam percarian akan Yesus. Hal ini menyebabkan gambar Yesus tidak koheren. Benarlah apa yang dikatakan oleh van Bruggen bahwa keanekaragaman gambar tentang Yesus sangat berkaitan dengan perbedaan sikap dalam memilih dan menilai sumber-sumber historis. ${ }^{23}$

Kriteria koherensi telah salah digunakan oleh para ahli kritik. Kriteria koherensi memang baik jika diterapkan secara adil. Keempat, Kriteria Memalukan. Yang dimaksudkan dengan kriteria rasa malu ini adalah bahwa informasi-informasi yang memalukan baik bagi gereja mula-mula, bagi murid-murid Yesus maupun bagi Yesus sendiri tidak ditemukan sesudah paskah. ${ }^{24}$ Artinya semua berita pasca peristiwa Pentakosta adalah berita yang memuliakan Yesus, dan semua yang bersifat meyakinkan

18 Evans, Merekayasa Yesus. Membongkar Pemutarbalikan Injil Oleh Ilmuwan Modern, 41.

19 Ibid.

${ }^{20}$ Komoszewski, Sawyer, and Wallace, Reinventing Jesus. Bagaimana Para Pemikir Skeptis Keliru Memahami Yesus Dan Menyesatkan Budaya Populer, 52-53.

21 Ibid., 54.

22 Ibid., 55.

23 Jacob van Bruggen, Kristus Di Bumi. Penuturan Kehidupan-Nya Oleh Murid-Murid Oleh PenulisPenulis Sezaman (Jakarta: BPK Gunung Mulia, n.d.), 4-5.

${ }^{24}$ Evans, Merekayasa Yesus. Membongkar Pemutarbalikan Injil Oleh Ilmuwan Modern, 42-43. 
bahwa gerakan kekristenan super dan dapat percaya. Semua ucapan yang berpotensi akan memalukan atau bahkan ucapan yang memalukan dianggap sebagai ucapan yang otenti. Jika murid-murid Yesus berkonspirasi untuk menciptakan gerakan yang baru dengan harapan bahwa anggotanya terus bertambah, maka mereka tidak akan memasukan cerita atau ucapan-ucapan yang tidak mendatangkan malu.

Jika Injil tentang Yesus telah dipalsukan oleh para murid-Nya maka pasti ucapanucapan yang memalukan tidak akan dimasukkan. Komoszewski dkk menyatakan: "satusatunya alaman mengapa perkataan yang menimbukan aib itu dimuat dalam kitab-kitab Injil ialah karena kata-kata itu benar-benar diucapkan." 25 Evans menegaskan hal dengan menyatakan: "fakta bahwa cerita itu masih dipertahankan dalam Injil dan tidak dihapuskan juga menunjukkan bahwa penulis Injil berupaya sedemikian rupa untuk menceritakan kebenaran." 26 Contoh ucapan-ucapan yang memalukan: Dalam Markus 13:32 Yesus menyatakan: "Tetapi tentang hari atau saat itu tidak seorang pun yang tahu, malaikat-malaikat di Surga tidak, dan Anak pun tidak, hanya Bapa saja." Perkataan Yesus ini akan memalukan diri-Nya sendiri, tetapi mengapa tetap dicantumkan?, Oleh sebab memang ucapan ini autentik.

Contoh yang lain adalah dalam Markus 11:2-6; Lukas 7:18-23 dalam pertanyaan Yohanes Pembaptis kepada Yesus: "Engkaukah yang akan datang itu atau haruskah kami menantikan orang lain?" Sangat memalukan, seorang nabi besar tidak mengetahui tentang Yesus. Untuk bersaksi tentang Yesus maka ia mendahului datang kepada Israel. Dalam jawaban Yesus juga sangat samar. Adalah baik jika Yesus menjawab pertanyaan Yohanes dengan menyatakan: Ya Akulah Dia. Faktanya ucapan ini tetap dipertahankan dalam kitab-kitab Injil, semuanya membuktikan satu hal yakni bahwa ucapan-ucapan yang berpotensi memalukan itu otentik.

Dari penelusuran di atas sangat meyakinkan bahwa bahwa autograf Injil-Injil ditulis sesuai dengan fakta yang terjadi meskipun penulisan kisah-kisah tersebut dilaksanakan puluhan tahun setelah Yesus terangkat ke surga. Jika naskah asli dari InjilInjil ditulis sesuai dengan fakta yang terjadi tentang perkataan dan perbuatan Yesus, bagaimana dengan salinan naskah-naskah tersebut, apakah masih sesuai dengan autografnya? Oleh karena naskah aslinya tidak dimiliki oleh orang Kristen sekarang, maka bagaimana memastikan bahwa salinan dari naskah-naskah dari kitab-kitab Injil sesuai dengan yang asli? Bart Ehrman menyatakan bahwa teks-teks Alkitab telah diubah pada saat penyalinan. ${ }^{27}$ Lebih lanjut Ehrman menyatakan: "We don't have the originals. We have only error hidden copies, and the vast majority of these are centuries removed from the originals and differant from them, evidently, in thousands of ways." 28 Ehrman menandaskan bahwa Alkitab telah diselewengkan pada saat dilakukan penyalinan. Ehrman menegaskan:

25 Komoszewski, Sawyer, and Wallace, Reinventing Jesus. Bagaimana Para Pemikir Skeptis Keliru Memahami Yesus Dan Menyesatkan Budaya Populer, 55.

26 Evans, Merekayasa Yesus. Membongkar Pemutarbalikan Injil Oleh Ilmuwan Modern, 42-43.

27 Bart Ehrman, Misquoting Jesus: The Story Behind Who Changed the Bible and Why (San Fransisco: HarperSanFransisco, 2005), 1.

28 Ibid., 7. 
Bukan hanya tidak memiliki naskah asli, kita bahkan tidak memiliki salinan dari naskah asli. Kita bahkan tidak memiliki salinan dari salinan dari naskah asli, atau salinan dari salinan dari salinan naskah asli. Kita hanya memiliki salinan yang ditulis jauh setelah naskah aslinya. ... Dan semua salinan ini saling berbeda satu sama lain dalam ribuan bagian... Tulisan-tulisan ini saling berbeda satu sama lain dalam begitu banyak bagian, sehingga kita bahkan tidak tahu berapa banyak perbedaan yang ada. ${ }^{29}$

Funk, Hoofer dan Yesus Seminar menyatakan: "Bahkan para penyalin yang hati-hati pun membuat kesalahan, seperti yang diketahui para korektor naskah siap cetak (proofreader). Jadi, kita tidak dapat mengklaim kita mengetahui persis apa yang merupakan teks asli dari tulisan mana pun dalam Alkitab." ${ }^{30}$ Kesan yang kita miliki dari pernyataan para ahli, khusunya Ehrman adalah kita tidak memiliki harapan terhadap salinan yang ada pada kita sekarang karena jauh dari naskah aslinya. Benarkah para penyalin telah melakukan perubahan yang membuat Injil yang sekarang dimiliki berbeda dengan Injil dalam naskah aslinya? Dalam menanggapi pernyataan dari Ehrman, Bock dan Wallace memberi solusi yang sangat baik kepada Ehrman: "ahli kritik teks biasanya tidak hanya mengandalkan penerima yang terakhir, tetapi juga bertanya kepada beberapa orang yang lebih dekat dengan sumber berita dan mereka yang dekat dengan para penulis naskah-naskah asli kitab-kitab Injil adalah bapa-bapa Gereja"31 Dengan perkataan lain, Ehrman tidak bisa langsung memfonis bahwa teks-teks yang ada sekarang telah berubah atau berbeda dari naskah aslinya, karena Ehrman sendiri tidak mengetahui naskah asli dari kitab-kitab Injil, bagaimana ia dapat menyatakan bahwa teks-teks sekarang telah jauh berbeda dengan teks-teks asli? Bock da Wallace memberi sanggahan dengan menyatakan:

Pernyataan Ehrman bahwa kita tidak memiliki salinan generasi ketiga atau keempat selain salinan-salinan yang ditulis jauh setelah itu memberi kesan yang menyesatkan. Bagaimana ia tahu seperti apa salinan-salinan generasi awal? Kita memiliki 10 sampai 15 salinan yang ditulis dalam kurun waktu satu abad sejak Perjanjian Baru selesai; tidak mungkinkan beberapa di antaranya adalah salinan generasi ketiga atau keempat, atau bahkan generasi kedua? Memang benar, semua berbentuk salinan fragmental, tetapi sebagian cukup susbstansial. Ehrman sendiri mengakui salah satu manuskrip tersebut mungkin merupakan salinan langsung dari naskah yang ditulis ratusan tahun sebelumnya. ${ }^{32}$

Komoszewski dkk menyatakan bahwa meskipun ada varian-varian dalam penerjamahan Perjanjian Baru secara khusus kitab-kitab Injil, tetapi varian-varian

${ }^{29}$ Darrell L. Bock and Daniel B. Wallace, Mendongkel Yesus Dari Tahta-Nya. Upaya Mutakhir Untuk Menjungkirbalikkan Iman Gereja Mengenai Yesus Kristus (Jakarta: Gramedia Pustaka Utama, 2009), 25.

30 Komoszewski, Sawyer, and Wallace, Reinventing Jesus. Bagaimana Para Pemikir Skeptis Keliru Memahami Yesus Dan Menyesatkan Budaya Populer, 63.

31 Bock and Wallace, Mendongkel Yesus Dari Tahta-Nya. Upaya Mutakhir Untuk Menjungkirbalikkan Iman Gereja Mengenai Yesus Kristus, 54.

32 Ibid., 53. 
tersebut sama sekali tidak mengubah maksud dasar dari Injil-Injil, tidak mengubah doktrin pokok yang hendak disampaikan para penulis kitab-kitab Injil. ${ }^{33}$ Apa yang disarankan oleh Bock dan Wallace bahwa jika terdapat keraguan terhadap Perjanjian Baru yang dimiliki Gereja/orang Kristen saat ini, apakah sesuai dengan autograf, maka sebaiknya bertanya kepada mereka yang dekat dengan sumber berita, perlu mendapat perhatian. SeseorangBock dan Wallace menulis:

Tertulianus, seorang bapa Gereja pada awal abad ketiga, mengecam lawanlawannya yang meragukan isi naskah asli dengan menyatakan: "Marilah, hai engkau yang memerlukan lebih banyak jawaban untuk keselamatanmu, datanglah ke Gereja-Gereja apostolik yang masih memiliki dan membacakan tulisan-tulisan otentik dari para rasul serta menampilkan wajah beberapa dari mereka" (Prescription again Heretics, bab 36). ${ }^{34}$

Selain dari kesaksian dari Tertulianus, yang menegaskan bahwa naskah asli dari tulisan para rasul masih dapat dijumpai, Bock dan Wallace juga menyatakan: Irenaeus, uskup agung dari Lyons pada akhir abad ke dua mencatat bahwa ia telah memeriksa salinan-salinan kitab wahyu dan mencatat manuskrip-manuskrip mana yang lebih awal untuk memastikan isi teks yang otentik. Ia berusaha memelihara isi teks yang asli, tetapi tidak menyatakan bahwa dokumen asli masih ada. Namun, usaha Irenaeus memelihara isi teks asli dan membandingkan salinan dengan manuskrip yang lebih awal tentu menggambarkan praktik dan usaha yang dilakukan oleh para penulis dan Bapa Gereja. ${ }^{35}$

Dengan demikian, sumber-sumber yang sangat dekat para rasul memastikan bahwa isi dari naskah-naskah asli masih dipertahankan. Kitab suci yang dimiliki oleh Gereja sekarang adalah seperti apa yang ditulis oleh mereka yang adalah saksi mata dari perkataan dan perbuatan Yesus dari Nazareth. Selain dari pembuktian kebenaran dari kesaksian Bapa-bapa Gereja, ada juga ilustrasi dari manuskrip. Bock dan Wallace berpendapat bahwa dua manuskrip tertua yang dimiliki sekarang, yaitu Papyrus 75 (P75) dan Codex Vaticanus (B) yang memiliki persamaan yang luar biasa tetapi yang

33 Komoszewski, Sawyer, and Wallace, Reinventing Jesus. Bagaimana Para Pemikir Skeptis Keliru Memahami Yesus Dan Menyesatkan Budaya Populer, 76. Komoszewski dkk mengakui bahwa varian-varian tekstual memang ada, yang meliputi: 1. Perbedaan Ejaan, misalnya perbedaan ejaan Ioanes dengan Ioannes, tetapi varian seperti demikian adalah kesalahan yang tak bermakna; 2. Perbedaan yang tidak mempengaruhi terjamahan atau memuat sinonim, misalnya penempatan kata sandang di depan nama orang yang selalu ada dalam bahasa Yunani, tetapi tidak ada dalam terjamahan bahasa Inggris juga tidak ada dalam bahasa Indonesia. 3Varian-varian yang bermakna tetapi tidak mampu bertahan. Varian-varian ini terdapat dalam satu manuskrip saja atau kelompok manuskrip yang sangat kecil kemungkinan mencerminkan kata-kata asli dari teks. Misalnya dalam 1 Tesalonika 2:9, manuskrip yang muda dari abad pertengahan memuat Injil Kristus, bukan Injil Allah (yang terdapat dalam hampir semua manuskrip). Varian ini bermakna, tetapi kecil kemungkinan bertahan. Kecil sekali satu manuskrip muda mungkin mengandung kata-kata asli jika tradisi tekstual dengan seragam mendukung varian lain. 4. Varian-varian bermakna dan mampu bertahan namun tidak berdampak pada doktrin pokok apapun. Misalnya dalam 1 Tesalonika apakah Paulus memakai: 2:7, apakah Paulus memakai epoi (lembut) atau nepoi (kanak-kanak), tetapi hal ini tidak mengganggu doktrin.

${ }^{34}$ Bock and Wallace, Mendongkel Yesus Dari Tahta-Nya. Upaya Mutakhir Untuk Menjungkirbalikkan Iman Gereja Mengenai Yesus Kristus, 54.

35 Ibid., 56. 
KEHANDALAN ALKITAB MENJADI FONDASI BAGI PENGAJARAN ... (Aprianus Ledrik Moimau)

satu tidak menjadi sumber bagi yang lain. P75 berusia 125 tahun lebih tua dari B, namun B disalin dari sumber yang lebih tua daripada P75. ${ }^{36}$ Dengan demikian, naskah-naskah yang kita miliki sekarang atau Alkitab (kitab-kitab Injil) sesuai dengan naskah asli dan dapat diandalkan untuk melihat bahwa apa yang dikatakan tentang Yesus adalah benar. Secara historis, kitab-kitab Injil dapat dipercaya. Kitab-kitab Injil bukanlah suatu rekayasa dari Gereja mula-mula atau teks-teks Perjanjian Baru telah mengalami perubahan dan perbedaan saat disalin, melainkan secara ketat berdasarkan berbagai argumentasi dan kesaksian dari Bapak-Bapak Gereja: Alkitab sekarang juga adalah Alkitab yang dahulu ditulis. Kehandalan naskah-naskan Perjanjian Baru semakin terlihat jika kita membandingkan naskah-naskah Perjanjian Baru dengan literatur kuno lainnya. Norman Geisler memberikan tabel perbandingan antar Perjanjian Baru dengan tulisan kuno lainnya sebagai berikut: ${ }^{37}$

\begin{tabular}{|c|c|c|c|}
\hline Penulis/Buku & $\begin{array}{c}\text { Tahun Catatan } \\
\text { Autografnya }\end{array}$ & Salinan Terawal & $\begin{array}{c}\text { Banyaknya } \\
\text { salinan/Renatan } \\
\text { waktu/\% Keakuratan }\end{array}$ \\
\hline Homer, Iliad & 800 S.M & & 643, thn? 95\% \\
\hline $\begin{array}{c}\text { Herodotus, } \\
\text { History }\end{array}$ & 480-425 S.M. & sekitar 900 T.M. & 8, (sekitar 350 th.) \\
\hline $\begin{array}{c}\text { Thucydides, } \\
\text { History }\end{array}$ & 460-400 S.M. & 900 T.M. & 8, (sekitar 1300 th.) \\
\hline Plato & 400 S.M. & 900 T.M. & 7, (sekitar 1300 th.) \\
\hline Demosthenes & 300 S.M. & 1100 T.M. & $200,($ sekitar 1400 th) \\
\hline $\begin{array}{c}\text { Caesar., Gallic } \\
\text { Wars }\end{array}$ & 100 - 44 S.M. & 900 T.M. & 10, (sekitar 1000 th.) \\
\hline $\begin{array}{c}\text { Livy, History of } \\
\text { Rome }\end{array}$ & 55 B.C - 17 T.M & $\begin{array}{c}\text { abad ke-4 } \\
\text { (sebagian) } \\
\text { sebagian besar } \\
\text { abad ke-10 }\end{array}$ & $\begin{array}{c}1 \text { bagian, (sekitar } 400 \text { th.) } \\
19 \text { salinan, (sekitar } 1000 \\
\text { th.) }\end{array}$ \\
\hline Tacitus, Annals & 100 T.M. & sekitar 1100 T.M. & 20, (sekitar 1000 th.) \\
\hline $\begin{array}{l}\text { Pliny Secundus, } \\
\text { Natural History }\end{array}$ & 61 - 113 T.M. & sekitar 850 T.M. & 7, (sekitar 750 th.) \\
\hline \multirow[t]{4}{*}{$\begin{array}{l}\text { Perjanjian Baru } \\
\text { - Kitab Suci Injil }\end{array}$} & 50 - 100 T.M. & $\begin{array}{l}\text { sekitar } 114 \\
\text { (fragment) }\end{array}$ & (10-30 th.) \\
\hline & & $\begin{array}{l}\text { sekitar } 200 \\
\text { (buku) }\end{array}$ & (100 th.) \\
\hline & & $\begin{array}{c}\text { sekitar } 250 \\
\text { (sebagian besar } \\
\text { Kitab Suci Injil) }\end{array}$ & (150 th.) \\
\hline & & sekitar 325 & (225 th.)/ 5366 Salinan, \\
\hline
\end{tabular}

36 Ibid., 57.

37 Norman L. Geisler and William E. Nix, A General Introduction to the Bible (Chicago: Moody, 1986 ), 408. 


\begin{tabular}{|l|c|c|c|}
\hline & $\begin{array}{c}\text { (Kitab Suci Injil } \\
\text { lengkap) }\end{array}$ & $\begin{array}{c}\text { 99\%+ Ketepatan } \\
\mathbf{5 3 6 6} \text { Salinan, } 99 \%+ \\
\text { Ketepatan }\end{array}$ \\
& & \\
\hline
\end{tabular}

Dari tabel perbandingan naskah-naskah Perjanjian Baru dengan catatan/literatur kuno yang lain, dapat disimpulkan bahwa:

1. Tidak ada naskah kuno yang mempunyai manuskrip/salinan lebih dekat dengan naskah asli dan jumlah lebih banyak dibanding dengan Perjanjian Baru.

2. Jarak antara penulisan pertama dengan penyalinan paling awal untuk Perjanjian Baru adalah sekitar 30 tahun untuk yang bersifat potongan dan kurang dari 250 tahun untuk keseluruhan naskah. Bandingkan dengan naskah kuno lain yang jarak antara penulisan pertama dengan penyalinan paling awal mencapai lebih dari 1000 tahun.

3. Tingkat keakuratan salinan Perjanjian Baru lebih tinggi dibanding naskah kuno lainnya yang dapat dibandingkan. Kebanyakan naskah tidak mempunyai jumlah manuskrip yang cukup supaya perbandingan dapat dilaksanakan. Penyalinan yang berjarak 1000 tahun dengan naskah aslinya membuat para sarjana tidak mempunyai cukup keyakinan untuk merekonstruksi naskah aslinya.

Sehubungan dengan perbandingan naskah-naskah Perjanjian Baru dengan naskahnaskah kuno yang lain, Paul Copan menyatakan: "Seandainya Perjanjian Baru secara tekstual benar-benar telah cacat bercela dan tak dapat dipercayai, maka dapatlah diperkatakan bahwa setiap Kitab kuno lainnya adalah juga cacat bercela dan tak dapat dipercaya."38 Perbandingan di atas juga terlihat bahwa baik dari jumlah salinan dan keakuratan penyakinan hanya Iliad, karya Homer yang berada dekat dengan Perjanjian Baru. Tentang perbandingan naskah-naskah Perjanjian Baru dengan tulisan-tulisan kuno yang lain, Craig L. Blomberg menyatakan bahwa intinya adalah bukti tekstual yang dituliskan oleh para pengarang Kitab Suci Injil jauh melebihi dokumentasi yang kita miliki untuk tulisan kuno lainnya, termasuk lusinan yang kita percaya telah terpelihara secara relatif utuh. Sama sekali tak ada landasan (dasar) untuk menyatakan bahwa edisi moderen standar Kitab Suci Injil Yunani tidak benar-benar mirip dengan apa yang para penulis Kitab Suci Injil tuliskan. ${ }^{39}$ Bruce Metzger menyatakan hal senada bahwa dia antara karya sastra Yunani, Iliad yang paling layak dibandingkan dengan Perjanjian Baru. ${ }^{40}$ Meskipun dari sisi jumlah dan keakuratan tulisan-tulisan kuno, hanya Iliad karya Homer yang dapat diperbandingkan dengan Perjanjian Baru, tetapi naskahnaskah Perjanjian Baru jauh lebih unggul.

\section{Tes Bukti Internal}

38 Paul Copan, True For You, But Not For Me (Minneapolis: Bethany House Publishers, 1998), 98.

39 Craig L. Blomberg, "The Historical Reliability of the New Testament," in Reasonable Faith: Christian Truth and Apologetics, ed. William Lane Craig (Wheaton: Crossway Books, 1994), 194.

${ }^{40}$ Josh McDowell, Apologetika, Bukti Yang Meneguhkan Kebenaran Alkitab Vol. 1, 1st ed. (Malang: Gandum Mas, 2007), 82. 
Bagaimana kita mengetahui bahwa Alkitab adalah benar dan dapat dijadikan dasar bagi rumusan Kristologi bahwa Yesus Kristus adalah Allah? Dalam pemaparan ini, kita akan melihat bagaimana Alkitab membuktikan dirinya benar. John W. Montgomery menyatakan bahwa saat meneliti suatu dokumen si peneliti harus mendengarkan dokumen yang dianalisis, jangan menganggap dokumen itu palsu kecuali sang pengarang sendiri yang mendiskualifikasi dirinya oleh karena berbagai kontradiksi dan fakta-fakta yang diketahui tidak akurat. ${ }^{41}$ Memang banyak ahli berapriori bahwa Alkitab salah tanpa membiarkan Alkitab memberi kesaksian tentang Alkitab sendiri.

Lukas memberi penjelasan kepada Teofilus: Teofilus yang mulia, Banyak orang telah berusaha menyusun suatu berita tentang peristiwa-peristiwa yang telah terjadi di antara kita, seperti yang disampaikan kepada kita oleh mereka, yang dari semula adalah saksi mata dan pelayan Firman. Karena itu, setelah aku menyelidiki segala peristiwa itu dengan seksama dari asal mulanya, aku mengambil keputusan untuk membukukannya dengan teratur bagimu, supaya engkau dapat mengetahui, bahwa segala sesuatu yang diajarkan kepadamu sungguh benar (Luk. 1:1-4). Sebelum menuliskan peristiwa tentang perkataan dan perbuatan Yesus, terlebih dahulu Lukas mengadakan penelitian untuk mengetahui apakah berita yang didengarnya benar demikian atau tidak. Menurut Lukas banyak orang mengetahui berita tersebut karena peritiwa itu terjadi di antara mereka. Dr. B. J. Bolang menyatakan dengan lantang bahwa sebagai yang berpendidikan, Lukas mengadakan penelitian secara teliti dan kritis sebelum menulis berita-berita tersebut. ${ }^{42}$ Bahkan dalam penelitiannya, menurut Boland, Lukas mendapat informasi itu dari saksi mata tentang ucapan dan perbuatan Yesus. ${ }^{43}$ William Barclay juga menegaskan hal yang sama bahwa Lukas telah melakukan penelitian dengan saksama kemudian menulis hasil penelitiannya. Lukas menulis berita yang terangung dan terbaik dalam dunia. ${ }^{44}$ Robert H. Stein menyatakan bahwa Lukas telah mengadakan penyelidikan secara hati-hati tentang peristiwa ini secara menyeluruh yaitu tentang Yesus Kristus dari permulaan. ${ }^{45}$ Penulisan Alkitab bukanlah dilakukan tanpa penyelidikan, melainkan dilakukan dengan sangat teliti, bahkan secara 'kritis'. Kombinasi pembuktian kebenaran tentang perkataan dan perbuatan Yesus sangat meyakinkan kebenarannya. Lukas sebagai orang terpelajar, tentu mengadakan penelitian dengan saksama dan dalam penelitiannya ia memperoleh bertita tersebut dari mereka yang adalah saksi mata.

Rasul Petrus, yang adalah saksi mata dari apa yang diucapkan dan dilakukan Yesus memberikan penegasan: "Sebab kami tidak mengikuti dongeng-dongeng isapan jempol manusia, ketika kami memberitahukan kepadamu kuasa dan kedatangan Tuhan kita, Yesus Kristus sebagai raja, tetapi kami adalah saksi mata dari kebesaran-Nya. Kami menyaksikan, bagaimana Ia menerima kehormatan dan kemuliaan dari Allah Bapa, ketika datang kepada-Nya suara dari Yang Mahamulia, yang menyatakan: "Inilah Anak yang Kukasihi, kepada-Nyalah Aku berkenan." (II Pet. 1:16-17). Injil Markus yang diakui

41 John W. Montgomery, History and Christianity (Downers Grove: Inter-Varsity Press, 1971), 20.

42 B. J. Boland, Tafsiran Alkitan Injil Lukas (Jakarta: BPK Gunung Mulia, 2008), 11-15.

43 Ibid., 15.

44 William Barclay, Pemahaman Alkitab Setia Hari, Injil Lukas (Jakarta: BPK Gunung Mulia, 2005), 10-12.

45 Robert H. Stein, The New American Commentary. An Exegetical and Theological Exposition of Holy Scripture LUKE (America: Broadman \& Holman Publisher, 1992), 66-68. 
oleh banyak ahli sebagai Injil yang pertama ditulis oleh Yohanes Markus, ternyata ia adalah penyambung lisah Petrus. ${ }^{46}$ Menarik, Petrus yang berada di belakang penulisan Injil Markus menyatakan bahwa apa yang mereka tulis adalah apa yang mereka dengar dan saksiakn dan benar demikian adanya bukan berita berdasarkan cerita nenek moyang atau isapan jempol.

Rasul Yohanes menyatakan: "Dan orang yang melihat hal itu sendiri yang memberikan kesaksian ini dan kesaksiannya benar, dan ia tahu, bahwa ia menyatakan kebenaran, supaya kamu juga percaya” (Yoh. 19:35). “..Apa yang telah kami lihat dan yang telah kami dengar itu, kami beritakan kepada kamu juga, supaya kamu pun beroleh persekutuan dengan kami. Dan persekutuan kami adalah persekutuan dengan Bapa dan dengan Anak-Nya, Yesus Kristus." (I Yoh. 1:3). Dalam mengomentari bukti internal kebenaran Alkitab, F.F. Bruce menyatakan bahwa perkataan bahwa para rasul adalah saksi mata apa yang diucapkan dan dilakukan Yesus adalah berita yang terus menerus diulang dengan tegas dan yakin. Ada begitu banyak saksi, maka apa yang mereka tuliskan harus sesuai dengan fakta yang telah terjadi. Bukan hanya saksi mata yang percaya yang harus diperhitungkan, melainkan orang-orang lain yang tidak percaya juga harus diperhitungkan. Jika murid-murid Yesus menyampaikan sesuatu yang tidak sesuai dengan fakta, mereka pasti diserang oleh mereka yang memang menunggu kesempatan untuk itu. ${ }^{47}$ Dengan demikian Alkitab membuktiakan bahwa Alkitab dapat dipercaya. Pengakuan Iman Gereja Perancis Pasal 3 berbunyi:

Kami mengaku bahwa Firman Allah ini tidak disampaikan atau dihasilkan oleh kehendak manusia, tetapi oleh dorongan Roh Kudus orang-orang berbicara atas nama Allah, menurut perkataan Rasul Petrus dalam 2 Petrus 1:2. Sesudah itu Allah, karena perhatian-Nya yang khusus kepada kita dan keselamatan kita, menyuruh hamba-hamba-Nya, yaitu Nabi-Nabi dan Rasul-Rasul, membukukan Firman-Nya yang telah dinyatakan. Dan Dia sendiri menulis dengan jari-Nya kedua loh batu Taurat. Oleh karena itu, kita menyebut tulisan-tulisan yang demikian Kitab-kitab Suci dan Ilahi. ${ }^{48}$

Orang Kristen percaya bahwa Allah yang menggerakan para penulis untuk menuliskan kitab-kitab tersebut (Kitab-kitab Injil) sesuai dengan apa yang dikehendakiNya

\section{Tes Bukti Eksternal.}

Adakah sumber-sumber di luar Alkitab yang mendukung ketepatan dan kredibilitas Alkitab? Alkitab sangat terbukti dapat dipercaya dari tes bukti bibliografi dan tes bukti internal. Meski demikian, masih ada satu tes bagi kebenaran Alkitab yaitu

46 Bruggen, Kristus Di Bumi. Penuturan Kehidupan-Nya Oleh Murid-Murid Oleh Penulis-Penulis Sezaman, 68-69; Lihat juga Jacob van Bruggen, Markus Injil Menurut Petrus (Jakarta: BPK Gunung Mulia, 2006), 10-12.

${ }^{47}$ McDowell, Apologetika, Bukti Yang Meneguhkan Kebenaran Alkitab Vol. 1, 109-110.

48 Thomas van den End, Enam Belas Dokumen Dasar Calvinisme (Jakarta: BPK Gunung Mulia, 2000), $20-21$. 
tes bukti eksternal. Ternyata bahwa ada banyak tulisan dari mereka yang hidup dekat dengan periode kehidupan Yesus. Eusebius misalnya, ia memelihara tulisan rasul Yohanes yang diterimanya dari Papias. Eusebius menulis:

"Penatua juga sering menyatakan hal ini: 'Markus, sebagai penerjemah Petrus, telah menuliskan dengan tepat segala sesuatu yang dia (Petrus) ceritakan, baik mengenai perbuatan maupun perkataan Kristus, namun tidak secara berurutan. Karena dia bukan pendengar maupun pendamping langsung dari Tuhan; tetapi setelah itu, sebagaimana yang telah saya katakan, dia mendampingi Petrus, yang meneruskan ajaran-Nya menurut kebutuhan, bukan menuangkan seluruh ucapan Tuhan secara runut. Jadi Markus tidak membuat kesalahan, dengan menuliskan segala sesuatu yang dia (Petrus) katakan; karena dia berpegang teguh pada satu hal, yaitu tidak menghilangkan satupun yang dia dengar, atau menambahkan apapun yang tidak benar dalam tulisannya." 49

Dari tulisan Eusebius di atas, jelas bahwa rasul Yohanes memberitahukan apa yang dilakukan Markus dan bagaimana ia menjadi juru tulis dari Petrus dalam menuliskan perbuatan dan perkataan Kristus. Markus menulis tepat seperti yang dikatakan Petrus. Hal ini merupakan sebagai bukti eksternal bahwa ada sumber di luar Alkitab yang menjelaskan bahwa Injil-Injil ditulis secara akurat.

Iranaeus, Uskup Lyons yang hidup tahun 180, ia adalah murid dari Polikarpus (murid dari rasul Yohanes) menulis bahwa dasar penulisan Injil sangat kuat sehingga tidak ada alasan bagi bidat untuk menyangkalnya, melainkan mereka mengakui dan menjadi landasan bagi mereka dalam mengembangkan ajaran mereka. ${ }^{50}$ Injil ditulis dengan baik dan tidak dapat disangkal oleh mereka yang menentang. Yosephus, seorang ahli sejarah Yahudi pernah menulis:

"kira-kira pada masa itulah hidup Yesus, seorang manusia bijaksana, bila ia boleh disebut manusia, karena ia adalah pelaku dari pelbagai pekerjaan yang luar biasa, guru dari orang-orang yang menerima kebenaran daripada-Nya dengan penuh sukacita. Ia menghimpun banyak orang baik Yahudi maupun bukan. Ia adalah sang Kristus. Dan ketika Pilatus, atas desakan para pemimpin di antara kita, menjatuhkan hukuman salib atas-Nya, mereka yang telah mengasihi-Nya sejak semula tidak meninggalkan-Nya, karena ia hidup kembali pada hari yang ketiga; seperti para nabi telah menubuatkannya dan banyak hal-hal lain yang menakjubkan mengenai Dia. Dan kaum Kristen, demikianlah mereka disebutkan menurut nama-Nya masih ada hingga hari ini". ${ }^{51}$

Sebenarnya apa yang dituliskan oleh Yosephus adalah inti dari Injil yaitu kematian dan kebangkitan Tuhan Yesus (I Kor. 15:1-5), dan apa yang merupakan inti dari Injil mendapat konfirmasi dari Yosephus. Tacitus seorang sejarawan Romawi juga menulis

${ }^{49}$ McDowell, Apologetika, Bukti Yang Meneguhkan Kebenaran Alkitab Vol. 1, 112.

50 Ibid.

${ }^{51}$ Merrill C. Tenney, Survei Perjanjian Baru (Malang: Gandum Mas, 2006), 249-50. 
bahwa Kristus adalah pemimpin orang Kristen, yang telah dihukum mati oleh Pontius Pilatus, Prokurator di Yudea, dan kekristenan dapat diredam, tetapi akhirnya berita itu tersebar luar karena kebangkitan Kristus. ${ }^{52}$ Dengan demikian terdapat bukti yang melimpah bahwa apa yang dicatat dalam Injil-Injil dikonfirmasi oleh tulisan mereka yang percaya (Bapak-bapak Gereja) maupun oleh para sejarawan pada masa itu.

Alkitab dapat diandalkan sebagai sumber yang benar dan teruji untuk mengenal Yesus Kristus. Alkitab bukanlah rekaan manusia yang ditulis tidak sesuai fakta, direkayasa untuk kepentingan murid-murid Yesus, melainkan para saksi mata dari perkataan dan perbuatan Yesus atau mereka yang memperoleh informasi dari para saksi mata telah menulisnya berdasarkan apa yang terjadi. Juga Alkitab yang sekarang diiliki oleh orang Kristen sama dengan tulisan asli, karena disalin secara bertanggung jawab. Ada bergitu banyak saksi dan bapak-bapak Gereja yang memelihara tulisantulisan tersebut dan memastikan bahwa tidak ada perbedaan antara naskah-naskah asli dengan salinan-salinan. Alkitab juga telah lulus tes kebenaran sejarah dan terbukti lebih unggul dari karya sastra kuno yang lain. Alkitab adalah tulisan yang memiliki otoritas ilahi.

Pengakuan Iman Gereja Belanda menyatakan:

Kita percaya, bahwa Kitab Suci ini berisi kehendak Allah secara sempurna, dan bahwa segala sesuatu yang harus dipercayai manusia untuk diselamatkan diajarkan di dalamnya dengan secukupnya. Sebab seluruh cara berbakti yang dituntut Allah dari kita tertulis di dalamnya dengan panjang lebar. Oleh karena itu, tidak boleh seorangpun, sekalipun ia seorang rasul, membawa ajaran lain daripada yang telah diajarkan kepada kita oleh Kitab suci, bahkan sekalipun ia seorang malaikat dari surga menurut perkataan rasul Paulus dalam Galatia 1:8. Larangan menambahi atau mengurangi Firman Allah (bnd. Ul. 12;32) menunjukkan betapa ajarannya sempurna dan lengkap. Juga tidak boleh tulisan-tulisan manusia, betapapun sucinya, disamakan dengan kitab-kitab ilahi. Pun tidak boleh kebiasaan disamakan dengan kebenaran Allah, (sebab kebenaran melebihi segala sesuatu), atau jumlah orang besar, atau ketuaan, atau suksesi zaman atau orang atau konsilikonsili, dekrit-dekrit atau keputusan-keputusan. Sebab sekalian orang adalah sumber dusta dan puncak kesia-siaan (bnd. Mzm. 62:10). Oleh sebab itu, kita menolak dengan sepenuh hati segala sesuatu yang tidak sesuai dengan patokan yang tidak dapat bersalah itu, sebagaimana diajarkan kepada kita oleh para rasul, katanya, Ujilah roh-roh, apakah mereka berasal dari Allah (1 Yoh. 4:1), begitu juga, jikalau seseorang datang kepadamu, dan ia tidak membawa ajaran ini, janganlah kamu menerima dia di dalam rumahmu (2 Yoh2:10). ${ }^{53}$

Demikian pula Pengakuan Iman Gereja Perancis menegaskan kewibaan Alkitab sebagai sumber dan patokan pengajaran dan iman Kristen (tentunya juga sebagai sumnber untuk mengenal Yesus):

\footnotetext{
52 Ibid., 250.

53 End, Enam Belas Dokumen Dasar Calvinisme, 23.
} 
Kami percaya, bahwa Firman Allah yang tercantum dalam kitab-kitab itu berasal dari Allah. Wibawanya diperoleh hanya dari Dia, bukan dari manusia. Dan karena Firman Allah itu merupakan patokan seluruh kebenaran dan berisi segala sesuatu yang perlu untuk berbakti kepada Allah dan demi keselamatan kita, maka manusia, bahkan malaikat pun, tidak diperbolehkan menambahi, mengurangi, atau mengubahnya. Maka dari itu, ketuaan, atau kebiasaan, atau jumlah besar orang, atau hikmat manusia, atau penilaian para ahli, atau keputusan-keputusan, atau edik-edik, atau konsili-konsili, atau penglihatan-penglihatan, atau mujizat-mujizat tidak boleh dipertentangkan dengan kitab suci. Bahkan sebaliknya, semua hal harus diselidiki, diatur dan dibaharui seturut Kitab Suci itu. Oleh sebab itu, kita menerima ketiga pengakuan iman, yaitu Pengakuan Iman Rasuli, Pengakuan Iman Nicea, dan Pengakuan Iman Athanasius, karena ketiganya sesuai dengan Firman Allah. ${ }^{54}$

\section{Hasil}

Berbagai tuduhan, kritikan, dan keberatan yang tujukan terhadap Alkitab bahwa Alkitab telah dipalsukan, tidak kebenaran dan kehandalan dalam membangun doktrindoktrin Kristen khususnya Alkitab tidak dapat dijadikan dasar dalam membangun kepercayaan kepada Yesus Kristus adalah tidak benar dan tidak berdasar. Berdasarkan tiga kriterian netral yang diajukan Sanders, tes bukti bibliografi, tes internal dan tes eksternal untuk menilai kebenaran dan suatu naskah sejarah, maka Alkitab memenuhi ketiga kriteria tersebut dan dengan demikian Alkitab memiliki kebenaran dan kehandahan dalam membangun iman kepada Yesus Kristus.

\section{Kesimpulan}

Berdasarkan kriteria pembuktian kebenaran yang diajukan oleh Sanders, maka Alkitab secara khusus Injil-Injil yang merupakan sumber primer tentang Yesus Kristus memenuhi ketiga kriteria. Dengan demikian, jelaslah bahwa kebenaran dan kehandalan Alkitab sebagai sumber informasi tentang Yesus Kristus dapat diterima dan diakui.

\section{Referensi}

Achtemeier, Paul J., Joel B. Green, and Marianne Meye Thompson. Introduction The New Testament. Its Literature Theology. Grand Rapids: Eerdmans, 2001.

Barclay, William. Pemahaman Alkitab Setia Hari, Injil Lukas. Jakarta: BPK Gunung Mulia, 2005.

Blomberg, Craig L. "The Historical Reliability of the New Testament." In Reasonable Faith: Christian Truth and Apologetics, edited by William Lane Craig. Wheaton: Crossway Books, 1994.

Bock, Darrell L. "The Words of Jesus in the Gospels: Live, Jive, or Memorex?" In Jesus Under Fire: Modern Scholarship Reinvents the Historical Yesus, edited by Michael J. 
Winkins and J. P Moreland. Grand Rapids: Zondervan, 1995.

Bock, Darrell L., and Daniel B. Wallace. Mendongkel Yesus Dari Tahta-Nya. Upaya Mutakhir Untuk Menjungkirbalikkan Iman Gereja Mengenai Yesus Kristus. Jakarta: Gramedia Pustaka Utama, 2009.

Boland, B. J. Tafsiran Alkitan Injil Lukas. Jakarta: BPK Gunung Mulia, 2008.

Bruggen, Jacob van. Kristus Di Bumi. Penuturan Kehidupan-Nya Oleh Murid-Murid Oleh Penulis-Penulis Sezaman. Jakarta: BPK Gunung Mulia, n.d.

_-_. Markus Injil Menurut Petrus. Jakarta: BPK Gunung Mulia, 2006.

Copan, Paul. True For You, But Not For Me. Minneapolis: Bethany House Publishers, 1998.

Drewes, B. E. Satu Injil Tiga Pekabar. Jakarta: BPK Gunung Mulia, 2006.

Ehrman, Bart. Misquoting Jesus: The Story Behind Who Changed the Bible and Why. San Fransisco: HarperSanFransisco, 2005.

End, Thomas van den. Enam Belas Dokumen Dasar Calvinisme. Jakarta: BPK Gunung Mulia, 2000.

Evans, Craig. Merekayasa Yesus. Membongkar Pemutarbalikan Injil Oleh Ilmuwan Modern. Yogyakarta: ANDI Offset, 2005.

Funk, Robert W., and Jesus Seminar. The Acts of Jesus: The Search of the Authentic Deeds of Jesus. San Fransisco: HarperSanFransisco, 1988.

Geisler, Norman L., and William E. Nix. A General Introduction to the Bible. Chicago: Moody, 1986.

Komoszewski, J. ED., M. James Sawyer, and Daniel B. Wallace. Reinventing Jesus. Bagaimana Para Pemikir Skeptis Keliru Memahami Yesus Dan Menyesatkan Budaya Populer. Jakarta: Literatur Perkantas, 2011.

McDowell, Josh. Apologetika, Bukti Yang Meneguhkan Kebenaran Alkitab Vol. 1. 1st ed. Malang: Gandum Mas, 2007.

Montgomery, John W. History and Christianity. Downers Grove: Inter-Varsity Press, 1971.

Sanders, C. Introduction in Research in English Literary History. New York: Macmillan Co, 1952.

Stein, Robert H. The New American Commentary. An Exegetical and Theological Exposition of Holy Scripture LUKE. America: Broadman \& Holman Publisher, 1992.

Tenney, Merrill C. Survei Perjanjian Baru. Malang: Gandum Mas, 2006.

Tylor, Vincent. The Formation of the Gospel Tradition. London: Macmillan, 1933. 